\title{
UPAYA MENINGKATKAN HASIL BELAJAR IPA SISWA KELAS IV MENGGUNAKAN MODEL STAD DAN NHT
}

\author{
Rahidatul Laila Agustina \\ Pendidikan Dasar \\ Sekolah Tinggi Keguruan dan Ilmu Pendidikan (STKIP) PGRI Banjarmasin, \\ Email: lailarahidatul@yahoo.com
}

\begin{abstract}
The purpose of this study was to increase the activity and student learning outcomes in science subjects on the concept of the structure of the plant to function using STAD model and NHT. This type of research is classroom action research (PTK), is collaboration . Data collection techniques used were interviews, observation and tests. Results of the analysis of the data showed an increase in activity for students to learn from the first cycle is pretty good and increased to very good in the second cycle. Results also showed increased student learning, both individually and classically. Students learning outcomes also increased from good in the first cycle to very good in the second cycle. It can be concluded that the use STAD model and NHT could improve the activity and learning outcomes IPA grade IV SDN Kampung Baru in the academic year 2015/2016.
\end{abstract}

Keyword: Learning outcomes, STAD, NHT.

\begin{abstract}
ABSTRAK
Tujuan dari penelitian ini adalah untuk meningkatkan aktivitas dan hasil belajar siswa pada mata pelajaran IPA pada konsep struktur tumbuhan dengan fungsinya menggunakan model STAD dan NHT. Jenis penelitian yang digunakan adalah Penelitian Tindakan Kelas (PTK), bersifat kolaborasi. Teknik pengumpulan data yang digunakan adalah wawancara, observasi dan tes. Hasil analisis data menunjukkan terjadi peningkatan aktivitas siswa dalam belajar dari siklus I adalah cukup baik dan meningkat menjadi sangat baik pada siklus II. Hasil belajar siswa juga menunjukkan peningkatan baik secara individu maupun klasikal. Hasil belajar siswa juga mengalami peningkatan dari kurang baik pada siklus I menjadi sangat baik pada siklus II. Dapat disimpulkan bahwa penggunaan model STAD dan NHT dapat meningkatkan aktivitas dan hasil belajar IPA siswa kelas IV SDN Kampung Baru tahun pelajaran 2015/2016.
\end{abstract}

Kata Kunci: Hasil belajar, STAD, NHT.

\section{PENDAHULUAN}

Proses pembelajaran ilmu pengetahuan alam (IPA) adalah proses aktif yang menekankan pada sesuatu yang dilakukan siswa, bukan pada sesuatu yang dilakukan guru. Pembelajaran IPA menekankan pada pemberian pengalaman langsung untuk mengembangkan kompetensi agar siswa menjelajahi dan memahami alam sekitar secara ilmiah. Pembelajaran IPA menekankan pada pengalaman langsung untuk mengembangkan kompetensi agar peserta didik mampu memahami alam sekitar melalui proses "mencari tahu" dan "berbuat" (Trianto, 2007:103).
Berdasarkan studi pendahuluan yang peneliti lakukan di kelas IV SDN Kampung Baru Kecamatan Beruntung Baru Kabupaten Banjar Provinsi Kalimantan Selatan, dari observasi awal dengan cara melakukan pengamatan pada tanggal 03 Agustus 2015, metode ceramah dalam pembelajaran masih sangat dominan di lakukan dengan komunikasi satu arah. Kepada siswa hanya disajikan fakta-fakta yang merupakan produk ilmiah, sehingga tidak dapat menarik minat. Dengan demikian ketiga kerangka dasar dalam pendidikan sains yaitu sikap, proses dan produk ilmiah tidak diterapkan, sehingga pembelajaran hanya menyajikan fakta fakta belaka dan cenderung bersifat hafalan. 
Selama kegiatan pembelajaran berlangsung peneliti melihat bahwa kebanyakan siswa belajar secara individu dan hanya menonjolkan kemampuan individualnya, tanpa memperhatikan teman lainnya. Di dalam kelas, siswa juga hanya mencatat materi pelajaran atau bisa juga dengan dikte oleh guru dan jarang membentuk kelompok dalam pembelajaran, kuis maupun kegiatan yang membuat siswa tertarik, tertantang dan lebih bersemangat dalam belajar, siswa cenderung pasif dalam pembelajaran.

Berdasarkan permasalahan diatas, maka perlu dikembangkan sebuah model yang mampu membuat siswa menjadi berminat dan bersemangat dalam mengikuti pembelajaran IPA, adanya aktivitas kelompok, kuis maupun kegiatan yang membuat siswa tertarik, tertantang dan lebih bersemangat dalam belajar, serta membuat siswa menjadi aktif. Model yang dirasa tepat untuk mengatasi permasalahan diatas adalah dengan menerapkan model pembelajaran kooperatif student team achievment divisions (STAD) dengan model pembelajaran numbered heads together (NHT).

Sintak dari 2 model kooperatif STAD dan NHT dianalisis untuk mencari kesamaan sifat dan memungkinkan untuk saling mendukung antara dua model tersebut. Contohnya salah satu kelebihan dari model STAD adalah model yang sederhana namun dapat mengukur perkembangan siswa, namun perkembangan siswa akan baik jika semua siswa aktif dalam kegiatan berkelompok. Untuk meningkatkan aktivitas siswa dalam kelompok, setiap anggota diberi nomor dan mendapat tanggung jawab terhadap tugas masing-masing, selain itu setiap siswa akan dipanggil sesuai nomor untuk menjawab pertanyaan dari guru. Penomoran ini merupakan bagian dari sintak model NHT. Selain itu fungsi lain dari tugas bernomor ini adalah untuk menyiapkan siswa dalam kuis individu, dimana merupakan salah satu ciri khas lain dari model STAD. Oleh karena itulah diharapkan dengan menggabungkan kelebihan-kelebihan dari model STAD dan NHT dimana model tersebut dapat meningkatkan aktivitas dan hasil belajar siswa. Adapun tahapan pelaksanaan penerapan model STAD dan NHT dilakukan dengan langkahlangkah sebagai berikut: tes awal untuk mengetahui skor awal, pembentukan kelompok heterogen, pemberian tugas kelompok berdasarkan nomor, diskusi kelompok, presentasi, pemanggilan nomor, kuis individu dan tes akhir.
Menurut Arends (Trianto, 2007:5-6) model pembelajaran mengacu pada pendekatan pembelajaran yang akan digunakan, termasuk di dalamnya tujuan-tujuan pengajaran, tahap-tahap dalam kegiatan pembelajaran, lingkungan pembelajaran dan pengelolaan kelas. Pembelajaran kooperatif (cooperative learning) merupakan bentuk pembelajaran dengan cara siswa belajar dan bekerja dalam kelompokkelompok kecil secara kolaboratif yang anggotanya terdiri dari empat sampai enam orang dengan struktur kelempok yang bersifat heterogen. Dalam pembelajaran ini akan tercipta sebuah interaksi yang lebih luas, yaitu interaksi dan komunikasi yang dilakukan antara guru dengan siswa dan siswa dengan guru (multi way traffic comunication) (Rusman, 2010:202-203).

Pembelajaran kooperatif merupakan model pembelajaran dengan menggunakan pengelompokan/tim kecil, yaitu antara empat sampai enam orang yang mempunyai latar belakang kemampuan akademik, jenis kelamin, ras atau suku yang berbeda (heterogen). Sistem penilaian dilakukan terhadap kelompok. Setiap kelompok akan memperoleh penghargaan (reward), jika kelompok mampu menunjukkan prestasi yang dipersyaratkan (Sanjaya, 2007:242-243).

Student Teams Achievement Division (STAD) dikembangkan oleh Robert Slavin dan teman-temannya di Universitas John Hopkin. Pembelajaran kooperatif tipe STAD merupakan model pembelajaran dengan menggunakan kelompok-kelompok kecil dengan jumlah anggota tiap kelompok 4-5 orang siswa secara heterogen. Diawali dengan penyampaian tujuan pembelajaran, penyampaian materi, kegiatan kelompok, kuis dan penghargaan kelompok (Trianto, 2007:52).

Slavin (2009:143), mengatakan STAD merupakan salah satu metode pembelajaran kooperatif yang paling sederhana, dan merupakan model yang paling baik untuk permulaan bagi para guru yang baru menggunakan pendekatan kooperatif. Lebih lanjut Slavin mengatakan guru menyajikan pembelajaran kemudian siswa bekerja dalam satu tim untk memastikan bahwa seluruh anggota tim telah menguasai pelajaran tersebut. Akhirnya seluruh siswa dikenai kuis tentang materi itu dimana pada saat kuis mereka tidak boleh saling membantu.

Gagasan utama STAD adalah untuk memotivasi siswa supaya dapat saling mendukung dan membantu satu sama lain dalam 
menguasai kemampuan yang diajarkan oleh guru. Jika para siswa ingin agar timnya mendapatkan penghargaan tim, mereka harus membantu teman satu timnya untuk mempelajari materi dan melakukan yang terbaik. Para siswa bekerjasama setelah guru menyampaikan materi pelajaran. Mereka boleh bekerja berpasangan dan membandingkan jawaban masing-masing, mendiskusikan setiap ketidaksesuaian, dan saling membantu satu sama lain jika ada yang salah dalam memahami. Meski bekerjasama, mereka tidak boleh saling bantu dalam mengerjakan kuis. Karena skor tim didasarkan pada kemajuan yang dibuat anggotanya (Slavin, 2009: 12-13).

Dalam STAD, para siswa dibagi dalam tim belajar yang terdiri atas empat orang yang berbeda-beda tingkat kemampuan, jenis kelamin dan latar belakang etniknya. Guru menyampaikan pelajaran, lalu siswa bekerja dalam tim mereka untuk memastikan bahwa semua anggota tim telah menguasai pelajaran. Selanjutnya, semua siswa mengerjakan kuis mengenai materi secara sendiri-sendiri, dimana saat itu mereka tidak diperbolehkan saling membantu. STAD telah digunakan dalam berbagai mata pelajaran yang ada, mulai dari matematika, bahasa, seni, sampai dengan ilmu sosial dan ilmu pengetahuan ilmiah lain, dan telah digunakan mulai dari siswa kelas dua sampai perguruan tinggi (Slavin, 2009:11-12).

Menurut Trianto (2011:62) "Numbered Heads Together (NHT) atau penomoran berpikir bersama adalah merupakan jenis pembelajaran kooperatif yang dirancang untuk mempengaruhi pola interaksi siswa dan sebagai alternatif terhadap struktur kelas tradisional". Teknik ini memberikan kesempatan kepada siswa untuk saling membagikan ide-ide dan mempertimbangkan jawaban yang paling tepat. Selain itu, teknik ini juga mendorong siswa untuk meningkatkan semangat kerja sama mereka.

Suprijono (2009:92) menyatakan bahwa pembelajaran dengan menggunakan metode Numbered Heads Together (NHT) diawali dengan Numbering. Guru membagi kelas menjadi kelompok-kelompok kecil. kemudian guru mengajukan beberapa pertanyaan. Pada kesempatan ini tiap-tiap kelompok menyatukan kepalanya "Heads Together" berdiskusi memikirkan jawaban atas pertanyaan dari guru. Langkah berikutnya guru memanggil peserta didik yang memiliki nomor yang sama dari tiaptiap kelompok mereka diberi kesempatan memberi jawaban atas pertanyaan yang telah diterimanya dari guru. Hal itu dilakukan terus hingga semua peserta didik dengan nomor yang sama dari masing-masing kelompok mendapat giliran memaparkan jawaban atas pertanyaan yang diberikan guru.

Belajar bukanlah berproses dalam kehampaan. Tidak pernah pula sepi dari berbagai aktivitas. Tidak pernah terlihat orang yang belajar tanpa melibatkan aktivitas raganya. Apalagi bila aktivitas belajar itu berhubungan dengan masalah belajar menulis, mencatat, memandang, membaca, mengingat, berpikir, latihan atau praktik dan sebagainya (Djamarah, 2011:38).

Pada prinsipnya belajar adalah berbuat. Tidak ada belajar kalau tidak ada aktivitas. Tanpa aktivitas, proses belajar tidak mungkin berlangsung dengan baik. Paul B. Diedrich dalam Sardiman menggolongkan kegiatan siswa sebagai berikut: (1) Visual activities, (2) Oral Activities, (3) Listening activities, (4) Writing activities, 5) Drawing activities, 6) Motor activities, (7) Mental activities, dan (8) Emotional activities (Sardiman 2011:95-101).

Hasil belajar merupakan perubahan perilaku secara keseluruhan bukan hanya salah satu aspek potensi kemanusiaan saja (Suprijono, 2009:7). Menurut Purwanto (2013:46), hasil belajar pada hakikatnya adalah perubahan perilaku akibat belajar. Perubahan perilaku disebabkan karena dia mencapai penguasaan atas sejumlah bahan yang diberikan dalam proses belajar mengajar. Pencapaian itu didasarkan atas tujuan pengejaran yang telah ditetapkan. Bloom (1956) dalam (Poerwanti, Widodo, Masduki, Pantiwati, Rofieq, dkk. 2009:1-23-1-30) mengklasifikasikan hasil belajar ke dalam tiga ranah yaitu: ranah kognitif, ranah afektif dan ranah psikomotorik.

Rencana pemecahan masalah yang akan digunakan dalam penelitian ini adalah dengan menggunakan model pembelajaran STAD dan NHT. Adapun langkah-langkah penerapan model pembelajaran STAD dan NHT dalam pemecahan masalah ini adalah: 1) melakukan tes awal untuk mengetahui skor awal siswa, yaitu untuk mengetahui kemampuan awal siswa sebelum dimulai pelajaran, 2) pembentukan kelompok heterogen, 3) pemberian tugas kelompok berdasarkan nomor, 4) diskusi kelompok, untuk menjawab permasalahan berdasarkan hasil kumpulan dari informasi yang didapat semua hasil kerja anggota kelompok, 5) presentasi, 6) 
pemanggilan nomor, 7) memberikan kuis individu, 8) tes akhir/evaluasi

Tujuan dari penelitian ini adalah meningkatkan aktivitas dan hasil belajar siswa pada mata pelajaran IPA pada konsep struktur bagian tumbuhan dan fungsinya dengan menggunakan model STAD dan NHT. Hipotesis dalam penelitian ini dikemu-kakan sebagai berikut: jika diterapkan model pembelajaran STAD dan NHT maka aktivitas dan hasil belajar siswa akan meningkat.

\section{METODE PENELITIAN}

Pendekatan penelitian yang digunakan dalam penelitian ini adalah pendekatan kualitatif. Menurut jenisnya penelitian yang digunakan adalah penelitian tindakan (Action Research) berupa penelitian tindakan kelas (Classroom Action Research). Penelitian Tindakan Kelas (PTK) adalah penelitian yang dilakukan oleh guru di dalam kelasnya sendiri melalui refleksi diri, dengan tujuan untuk memperbaiki kinerjanya sebagai guru, sehingga hasil belajar siswa menjadi meningkat (Wardhani 2008:1.4). Prosedur penelitian berbentuk siklus dengan menggunakan model yang merupakan adaptasi dari model yang dikembangkan oleh Kemmis \& Taggart (1998). Setiap siklus meliputi planning (perencanaan), action (tindakan) dan observe

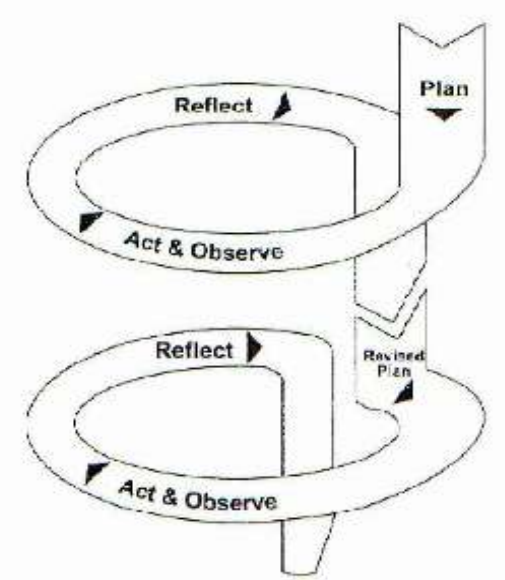

(pengamatan) dan reflection (refleksi) dengan struktur gambar sebagai berikut:

\section{Gambar 1: Struktur Jalannya Siklus PTK}

(Kemmis \& Taggart, 1988)

Definisi operasional variabel dalam penelitian ini adalah sebagai berikut:

1) Model STAD, adalah salah satu model pembelajaran kooperatif yang terdiri dari lima komponen utama yaitu: pembentukan kelompok kecil secara heterogen yang beranggotakan 4-5 orang siswa, penyampaian materi, pembelajaran dalam tim, kuis dan rekognisi tim.

2) Model NHT, adalah model pembelajaran kooperatif yang terdiri dari empat fase yaitu, penomoran, pengajuan pertanyaan, berpikir bersama dan menjawab

3) Model STAD dan NHT, adalah penggabungan sintaks model pembelajaran berdasarkan aspek khas dari masing masing model yang saling mendukung seperti pemberian tugas maupun pertanyaan untuk tiap individu sesuai nomor masing-masing untuk model NHT, skor perkembangan individu (kuis) untuk model STAD dimana skor perkembangan ini berpengaruh dalam nilai tim.

4) Aktivitas Belajar IPA, adalah segala kegiatan yang dilakukan dalam proses interaksi guru dan siswa dalam mencapai tujuan pembelajaran IPA. Aktivitas guru meliputi kegiatan guru dalam menyampaikan dan menyajikan materi pelajaran IPA, kegiatan membimbing siswa dalam kelompok selama pembelajaran berlangsung. Sedangkan aktivitas siswa yaitu mengenai proses pembelajaran IPS, baik aktivitas siswa dalam belajar, dalam kerja kelompok ataupun kinerja siswa secara individual.

5) Hasil Belajar Siswa, adalah penguasaan siswa terhadap materi pembelajaran yang diukur dengan skor tes akhir mata pelajaran IPA yang diperoleh siswa setelah mengikuti pembelajaran.

Penelitian tindakan kelas ini dilaksanakan di SDN Kampung Baru Kecamatan Beruntung Baru Kabupaten Banjar yang beralamat di Jl. Handil Gayam RT. 02 Kecamatan Beruntung Baru, dengan Kepala Sekolah yaitu Bapak Supriadi, S.Pd.SD. SDN Kampung Baru terletak di daerah pedesaan yang jauh dari kota Banjarmasin sebagai ibukota Provinsi maupun dengan ibukota kabupatennya yaitu Banjar. Penelitian ini dilakukan pada siswa kelas IV SDN Kampung Baru dengan siswa yang berjumlah 12 siswa terdiri dari 10 laki-laki dan 2 perempuan pada semester ganjil tahun ajaran 2015/2016.

Teknik pengumpulan data dalam penelitian ini menggunakan observasi dan tes. Tes digunakan untuk mengukur keberhasilan hasil belajar siswa dan observasi dilakukan untuk mengukur aktivitas siswa dalam pembelajaran. 
Teknik analisa data dalam penelitian ini dilakukan dengan reduksi data, paparan data dan menarik kesimpulan. Indikator keberhasilan dari penelitian ini dapat dilihat pada tabel berikut:

\section{Tabel 1: Deskripsi Pengkategorian Aktivitas dan Hasil Belajar Siswa}

\begin{tabular}{|l|c|}
\hline Interprentasi & Kualifikasi \\
\hline $0 \%-20 \%$ & Sangat Kurang \\
\hline $21 \%-40 \%$ & Kurang Baik \\
\hline $41 \%-60 \%$ & Cukup Baik \\
\hline $61 \%-80 \%$ & Baik \\
\hline $81 \%-100 \%$ & Sangat Baik \\
\hline
\end{tabular}

(Diadaptasi dari Riduwan, $2012: 89$ )

\section{HASIL DAN PEMBAHASAN}

\section{Hasil}

\section{Aktivitas Siswa dalam Pembelajaran}

Berdasarkan hasil pengamatan yang dilakukan peneliti terhadap kegiatan siswa dalam proses pembelajaran baik siklus I maupun siklus II terjadi peningkatan aktivitas dimana banyak siswa yang semakin aktif dalam belajar. Hal ini dapat dilihat dari hasil penelitian yang menunjukkan adanya peningkatan aktivitas siswa dalam pembelajaran dengan menggunakan gabungan model pembelajaran STAD dan NHT yang dapat dilihat pada lembar observasi aktivitas siswa secara individu pada siklus I pertemuan 1 dengan rata-rata 2,5 dan aktivitas siswa secara kelompok memperoleh presentase 45\% dengan predikat cukup aktif. Sedangkan pada pertemuan 2 aktivitas siswa secara individu meningkat memperoleh skor rata-rata nilai 2,75 dengan predikat aktif, sedang aktivitas siswa secara kelompok memperoleh presentase 53,33\% dengan predikat cukup aktif. Sedang siklus II pertemuan 1 dengan rata-rata 3,25 dan aktivitas siswa secara kelompok memperoleh presentase $61,67 \%$ dengan predikat aktif. Sedangkan pada pertemuan 2 aktivitas siswa secara individu meningkat memperoleh skor rata-rata nilai 3,62 dengan predikat aktif, sedang aktivitas siswa secara kelompok memperoleh presentase $86,6 \%$ dengan predikat sangat aktif. Semua aktivitas yang direncanakan dapat terlaksana dengan baik. Kenyataan ini menunjukan ada peningkatan proses pembelajaran oleh siswa. Adapun perbandingan persentase nilai keaktifan siswa dapat dilihat pada tabel berikut ini:

Tabel 1: perbandingan aktivitas individu siswa siklus I dan II

\begin{tabular}{|c|c|c|}
\hline \multirow{2}{*}{} & \multicolumn{2}{|c|}{$\begin{array}{c}\text { Rata-rata Aktivitas individu } \\
\text { siswa }\end{array}$} \\
\cline { 2 - 3 } & Siklus I & Siklus II \\
\hline Pertemuan 1 & 2,5 & 3,25 \\
\hline Pertemuan 2 & 2,75 & 3,62 \\
\hline & Aktivitas kelompok siswa \\
\hline Pertemuan 1 & $45 \%$ & $61,67 \%$ \\
\hline Pertemuan 2 & $53,33 \%$ & $86,66 \%$ \\
\hline
\end{tabular}

\section{Hasil Belajar Siswa}

Berdasarkan hasil pengamatan yang dilakukan peneliti terhadap hasil belajar siswa dengan menggunakan model pembelajaran STAD dan NHT dalam proses pembelajaran baik siklus I maupun siklus II terjadi peningkatan hasil belajar. Hal ini dapat dilihat dari siklus 1 pertemuan 1 dengan tingkat ketuntasan dengan persentase $33 \%$ siswa tuntas dan $67 \%$ siswa tidak tuntas, pada pertemuan 2 dengan tingkat ketuntasan persentase $50 \%$ siswa yang tuntas dan $50 \%$, dan hasil tes formatif siklus I dengan tingkat ketuntasan $58 \%$ siswa tuntas dan $42 \%$ siswa tidak tuntas. Sedang siklus II pada pertemuan 1 dengan persentase $75 \%$ siswa tuntas dan $25 \%$ siswa tidak tuntas, pada pertemuan 2 dengan tingkat ketuntasan persentase $83 \%$ siswa yang tuntas dan $17 \%$ siswa tidak tuntas, dan hasil siklus II (formatif II) dengan tingkat ketuntasan 92\% siswa tuntas dan $8 \%$ siswa tidak tuntas. Dilihat dari rata-rata nilai tiap pertemuan ada peningkatan yang sangat signifikan, dan telah mencapai tingkat ketuntasan secara klasikal karena dilihat dari presentase ketuntasan sudah berada diatas standar ketuntasan minimal. Adapun perbandingan persentase nilai hasil siswa dapat dilihat pada diagram berikut ini: 


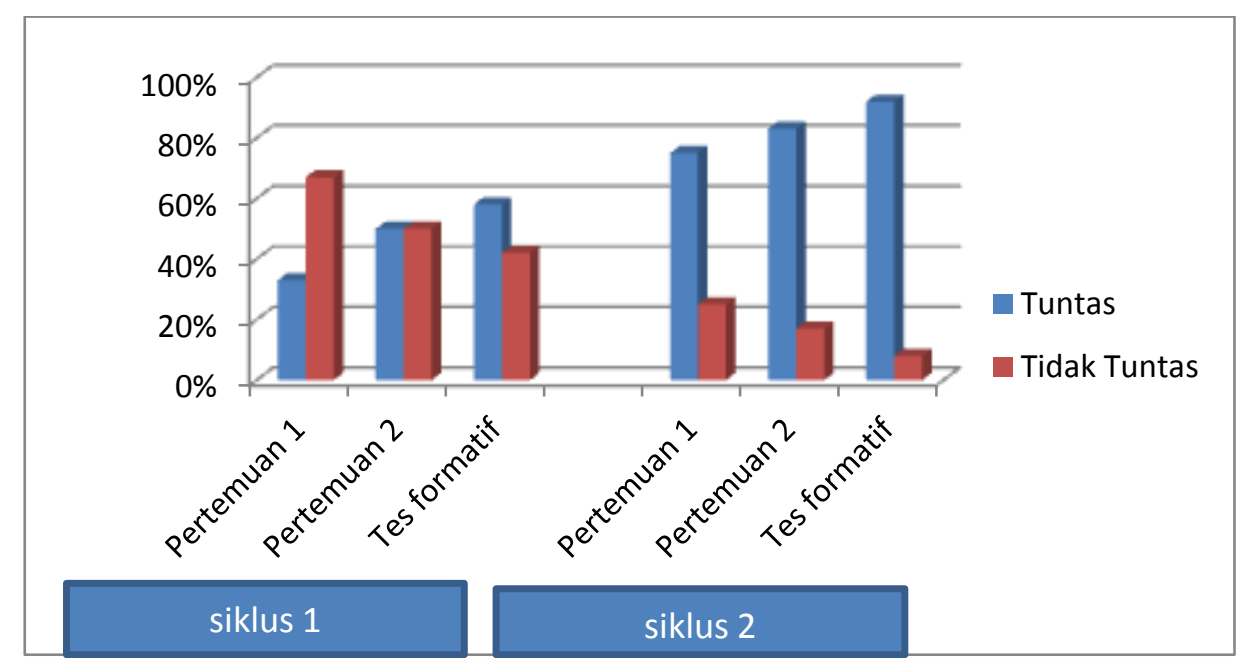

Gambar 1: Perbandingan Hasil Belajar Siswa Siklus I Dan II

\section{Pembahasan}

Penerapan model pembelajaran STAD dengan NHT dapat meningkatkan aktivitas belajar siswa dengan bukti-bukti yang dapat ditunjukkan dari hasil pengamatan terhadap aktivitas belajar siswa selama proses pembelajaran berlangsung baik pada siklus I maupun siklus II yang selalu mengalami peningkatan disetiap indikatornya. Jika ditelaah secara lebih mendalam, uraian-uraian diatas sejalan dengan teori yang dikemukakan olehHal ini sesuai dengan pendapat Rusman (2011:202203) yang menyatakan bahwa pembelajaran kooperatif (cooperative learning) merupakan bentuk pembelajaran dengan cara siswa belajar dan bekerja dalam kelompok-kelompok kecil secara kolaboratif yang anggotanya terdiri dari empat sampai enam orang dengan struktur kelempok yang bersifat heterogen. Dalam pembelajaran ini akan tercipta sebuah interaksi yang lebih luas, yaitu interaksi dan komunikasi yang dilakukan antara guru dengan siswa dan siswa dengan guru (multi way traffic comunication). Salah satu aksentuasi model pembelajaran kooperatif adalah interaksi kelompok. Interaksi kelompok merupakan interaksi interpersonal (interaksi antaranggota). Interaksi kelompok dalam pembelajaran kooperatif bertujuan mengembangkan intelegensi interpersonal (Suprijono,2009:62).

Gagasan utama STAD adalah untuk memotivasi siswa supaya dapat saling mendukung dan membantu satu sama lain dalam menguasai kemampuan yang diajarkan oleh guru. Jika para siswa ingin agar timnya mendapatkan penghargaan tim, mereka harus membantu teman satu timnya untuk mempelajari materi dan melakukan yang terbaik. Para siswa bekerjasama setelah guru menyampaikan materi pelajaran. Mereka boleh bekerja berpasangan dan membandingkan jawaban masing-masing, mendiskusikan setiap ketidaksesuaian, dan saling membantu satu sama lain jika ada yang salah dalam memahami. Meski bekerjasama, mereka tidak boleh saling bantu dalam mengerjakan kuis. Karena skor tim didasarkan pada kemajuan yang dibuat anggotanya (Slavin, 2009:12-13).

Slavin (2009:143), mengatakan STAD merupakan salah satu metode pembelajaran kooperatif yang paling sederhana, dan merupakan model yang paling baik untuk permulaan bagi para guru yang baru menggunakan pendekatan kooperatif. lebih lanjut Slavin mengatakan guru menyajikan pembelajaran kemudian siswa bekerja dalam satu tim untk memastikan bahwa seluruh anggota tim telah menguasai pelajaran tersebut. Akhirnya seluruh siswa dikenai kuis tentang materi itu dimana pada saat kuis mereka tidak boleh saling membantu. Menurut Trianto (2011:62)“Numbered Heads Together (NHT) atau penomoran berpikir bersama adalah merupakan jenis pembelajaran kooperatif yang dirancang untuk mempengaruhi pola interaksi siswa dan sebagai alternatif terhadap struktur kelas tradisional". Teknik ini memberikan kesempatan kepada siswa untuk saling membagikan ide-ide dan mempertimbangkan jawaban yang paling tepat. Selain itu, teknik ini juga mendorong siswa untuk meningkatkan semangat kerja sama mereka. 
Suprijono (2009:92) menyatakan bahwa pembelajaran dengan menggunakan metode Numbered Heads Together (NHT) diawali dengan Numbering. Guru membagi kelas menjadi kelompok-kelompok kecil. kemudian guru mengajukan beberapa pertanyaan. Pada kesempatan ini tiap-tiap kelompok menyatukan kepalanya "Heads Together" berdiskusi memikirkan jawaban atas pertanyaan dari guru.

Pembelajaran akan lebih bermakna jika siswa diberi kesempatan untuk berpartisipasi dalam berbagai aktivitas kegiatan pembelajaran, sehingga siswa mampu mengaktualisasikan kemampuannya di dalam dan di luar kelas (Rusman, 2011:323). Hal ini didukung oleh pendapat (Sardiman, 2011:17) aktivitas siswa merupakan syarat mutlak bagi berlangsungnya interaksi belajar mengajar. Aktivitas siswa dalam hal ini baik secara fisik maupun secara mental aktif. Inilah yang sesuai dengan konsep cara belajar siswa aktif. Jadi tidak ada gunanya guru melakukan kegiatan interaksi belajar mengajar kalau siswa hanya pasif saja. Sebab para siswalah yang belajar, maka merekalah yang harus melakukannya.

Berdasarkan penelitian Tindakan Kelas Siklus I dan Siklus II dapat diketahui bahwa ada peningkatan hasil belajar siswa. Hal ini sesuai dengan teori Sudjana (2013:45) mengemukakan bahwa setiap proses belajar mengajar keberhasilannya diukur dari seberapa jauh hasil belajar yang dicapai siswa, disamping diukur dari segi prosesnya. Hasil belajar merupakan perubahan perilaku secara keseluruhan bukan hanya salah satu aspek potensi kemanusiaan saja (Suprljono, 2009:7). Menurut Purwanto (2013:46) Hasil belajar pada hakikatnya adalah perubahan perilaku akibat belajar. Perubahan perilaku disebabkan karena dia mencapai penguasaan atas sejumlah bahan yang diberikan dalam proses belajar mengajar. Pencapaian itu didasarkan atas tujuan pengejaran yang telah ditetapkan.

\section{SIMPULAN DAN SARAN}

Berdasarkan hasil penelitian tindakan kelas yang peneliti lakukan yaitu tentang upaya meningkatkan hasil belajar siswa melalui model STAD dan NHT, maka dapat disimpulkan sebagai berikut: Penerapan model pembelajaran STAD dan NHT dapat meningkatkan aktivitas dan hasil belajar IPA siswa kelas IV SDN
Kampung Baru. Sintaks/langkah-langkah dalam pembelajaran meliputi, tes awal untuk mengetahui skor awal, pembentukan kelompok heterogen, pemberian tugas kelompok berdasarkan nomor, diskusi kelompok, presentasi, pemanggilan nomor, kuis individu dan evaluasi. Pada akhir siklus I dan siklus II dilakukan tes akhir untuk menilai sejauh mana peningkatan hasil belajar siswa melalui penerapan model STAD dan NHT. Jika ditinjau dari peningkatan hasil belajar, maka pada siklus II terjadi peningkatan hasil belajar. Terjadi peningkatan hasil belajar siklus I dari $33 \%$ dan meningkat menjadi $83 \%$ pada siklus II. Peningkatan aktivitas belajar sebesar $50 \%$ pada siklus II. Maka terjadi peningkatan aktivitas belajar siswa sebesar $45 \%$ pada siklus II. Penerapan kedua model pembelajaran dapat meningkatkan hasil belajar siswa, ditunjukkan dengan hasil kegiatan individu dan kelompok yang meningkat dari siklus I ke siklus II. Hasil tes awal dan tes akhir juga menunjukkan kenaikan nilai siswa.

Berdasarkan temuan diatas, peneliti menyarankan hal-hal sebagai berikut: Guru hendaknya dapat mengelola waktu dengan cermat, memberikan pemahaman dan penjelasan lebih detail kepada siswa tentang aturan pembelajaran dengan nomor dan kuis dalam pembelajaran. Diperlukan persiapan yang cukup matang untuk menerapkan model pembelajaran STAD dan NHT, sehingga guru harus mampu menentukan atau memilih topik yang benarbenar bisa diterapkan dengan model pembelajaran STAD dan NHT dalam proses belajar mengajar sehingga diperoleh hasil yang optimal. Pemberian penghargaan kelompok (team rewards) bisa dibuat secara bervariasi bukan hanya berupa hadiah (barang), tetapi bisa juga berupa sertifikat yang berguna bagi siswa, sehingga siswa lebih termotivasi untuk menjadi kelompok terbaik. Untuk siswa selama proses pembelajaran berlangsung disarankan agar siswa dapat bekerjasama dengan kelompoknya. Sehingga dapat merangsang siswa untuk aktif dalam proses belajar mengajar. Siswa hendaknya tidak malu menanyakan materi yang dianggap sulit kepada teman yang lainnya. Karena pembelajaran tidak hanya terbatas pada penjelasan guru. Hendaknya siswa tidak segan membantu temannya yang berkemampuan kurang. Karena dengan mengajarkan teman lain, semakin semakin bertambah pengetahuannya. Siswa agar lebih meningkatkan keaktifan di kelas seperti bertanya, mengungkapkan pendapat dan 
maju di depan kelas. Untuk lebih meningkatkan hasil belajar siswa disarankan sebaiknya guru sebelum memulai pelajaran hendaknya mengingatkan kembali materi-materi pelajaran sebelumnya melalui pertanyaan-pertanyaan. Sebab diketahui beberapa siswa belum begitu paham secara mendalam tentang materi yang akan diajarkan.

\section{DAFTAR RUJUKAN}

Djamarah, Syaiful Bahri. 2011. Psikologi Belajar. Jakarta: Rineka Cipta.

Kemmis, S. \& Mc. Tagart, R. 1988. The Action Research Planner. Deakin University Press. Victoria.

Poerwanti, Endang, Widodo, Masduki, Pantiwati, Rofiek, Utumo. 2009. Assesmen Pembelajaran di SD. Direktorat Jenderal Pendidikan Tinggi: Departemen Pendidikan Nasional.

Purwanto. 2013. Evaluasi Hasil Belajar. Yogyakarta: Pustaka Pelajar.

Rusman. 2011. Model-Model Pembelajaran: Mengembangkan Profesionalisme Guru. Jakarta: Rajawali Pers.

Sanjaya, Wina. 2010. Strategi Pembelajaran Berorientasi Standar Proses Pendidikan. Jakarta: Kencana Prenada Media.
Sardiman. A.M. 2011. Interaksi \& Motivasi Belajar Mengajar. Jakarta: Rajawali Press. Slavin, Robert. E. 2009. Cooperative Learning: Teori, Riset dan Praktek. Bandung: Nusa Media.

Sudjana. 2013. Dasar-dasar Proses Belajar Mengajar. Bandung: Sinar Baru Algensindo.

Suprijono, Agus. 2009. Cooperative Learning: Teori dan Aplikasi PAIKEM. Surabaya: Pustaka Pelajar.

Trianto. 2007. Model Pembelajaran Terpadu Dalam Teori dan Praktek. Jakarta: Prestasi Pustaka Publisher.

Trianto. 2007. Model-model Pembelajaran Inovatif Berorientasi Konstruktivistik: Konsep Landasan Teoritis Praktis dan Implementasinya. Jakarta: Prestasi Pustaka Publisher.

Trianto. 2011. Mendesain Model Pembelajaran Inovatif-Propgresif Konsep Landasan dan Implementasinya pada Kurikulum Tingkat Satuan Pemdidikan (KTSP). Jakarta: Kencana.

Whardani, I.G.A.K. \& Kuswaya W. 2008. Penelitian Tindakan Kelas. Jakarta: Universitas Terbuka. 